\title{
Measuring Exchange Market Pressure in South Africa: An Application of the Girton-Roper Monetary Model
}

Emmanuel Ziramba

Department of Economics, University of South Africa

\begin{abstract}
The monetary approach to the balance of payments is based on the assumption of a fixed exchange rate, while its approach to exchange rate determination is based on perfectly flexible exchange rate. Another monetary model called the Exchange Market Pressure model (EMP) was designed to capture the properties of the managed float. This paper applies the monetary model of the EMP to the South African experience with floating exchange rate and managed float systems over the period 1970-1993. We show that the EMP model is superior to the traditional monetary approach. We do not find evidence of the impact of domestic real income on EMP. Diagnostic tests suggest that the model is well specified and the residuals pass the typical checking.
\end{abstract}

JEL F31, 37

\section{Introduction}

South Africa is the economic powerhouse of Africa. Its gross domestic product comprises approximately 25 per cent of the entire continent's GDP. Its industrial output is 40 per cent of total output; and its mineral production is 45 per cent, while its electricity generation constitutes more than 50 per cent of that of the entire continent. This makes it particularly interesting to study the South African economy. Table 1 below gives selected economic indicators for South Africa.

Table 1

South Africa: Selected Economic Indicators

\begin{tabular}{|l|c|c|c|c|}
\hline & $\mathbf{1 9 9 9}$ & $\mathbf{2 0 0 0}$ & $\mathbf{2 0 0 1}$ & $\mathbf{2 0 0 2}$ \\
\hline Real GDP growth (in per cent) & 2.0 & 3.5 & 2.8 & 3.0 \\
\hline Unemployment rate (in per cent) & 23.3 & 25.8 & 29.5 & 30.5 \\
\hline Change in consumer prices (end of period) & 2.3 & 7.6 & 3.8 & 12.1 \\
\hline Change in broad money (in per cent) & 10.1 & 7.5 & 16.7 & 12.8 \\
\hline $\begin{array}{l}\text { Current account balance (percentage of GDP, } \\
\text { deficit -) }\end{array}$ & -0.5 & -0.4 & -0.3 & 0.3 \\
\hline Gross official reserves (billions of U.S. dollars) & 7.4 & 7.5 & 7.5 & 7.6 \\
\hline Exchange rate, rand per U.S dollar & 6.15 & 7.57 & 12.09 & 8.66 \\
\hline Change in real effective exchange rate (in per cent) & -5.2 & -3.0 & -13.5 & -17.2 \\
\hline
\end{tabular}


South Africa provides a good example for testing the monetary model for EMP for two reasons. First, it can be treated as a small open economy, in the sense that world monetary conditions and world prices are considered to be given. Second, after the collapse of the Bretton Woods system in 1971, South Africa experimented with a variety of exchange rate arrangements. Van der Merwe (1996: 1) classified the evolution of the exchange rate system in South Africa since the Second World War into five periods, namely:

- 1945-1971: An era dominated by the Bretton Woods arrangements of fixed but adjustable exchange rates;

- 1971-1979: A period characterised by the disintegration of the Bretton Woods system and attempts by South Africa to maintain a relatively stable exchange rate of the rand;

- 1979-1985: A period of considerable reform of the exchange rate arrangements aimed at developing the market for foreign exchange and a floating exchange rate system;

- 1985-1994: A period in which socio-political events forced the authorities to revert to more direct control measures to manage the exchange rate of the rand, and

- 1994-1995: The first two years under the new Government of National Unity, during which South Africa's international financial relations were normalised and steps were taken to develop a forward market with less central bank involvement and progressive relaxation of exchange control.

In this study we are particularly interested in the three middle periods, that is, those between 1970 and 1994. During this period, the authorities administratively fixed or intervened in the foreign exchange market to influence the rand exchange rate. South African monetary authorities announced a policy of independent managed floating exchange rate on 21 June 1974 (Van der Merwe, 1996). For most of the 1980s and early 1990s, the South African government adhered to a managed floating exchange rate regime, with the central bank intervening periodically at its discretion. When the Reserve Bank intervened in the foreign exchange market, it could buy and sell dollars, supporting the exchange rate of the rand in the process (Gidlow, 2004). This policy was changed in 1999, when it was thought to be no longer viable for supporting the rand. Given the historical developments in exchange rate policy in South Africa, it is felt that the EMP model is particularly applicable.

This paper is presented in six sections. The second section briefly outlines a simple monetary model of EMP. In the third section a brief empirical literature review is given. The fourth section presents the EMP estimation result for the period 1970-1993. The fifth section discusses the evidence from raw data. Finally, the sixth section presents the summary and main conclusions of the paper.

\section{2}

\section{Girton-Roper exchange market pressure (EMP) model}

The central theme of the monetary approach to the balance of payments is that, under the fixed exchange rate system, excess money supply causes loss of international reserves, which results in balance of payments deficits. Under a flexible exchange rate system, this pressure on the balance of payments is absorbed by a depreciating currency. EMP arises owing to disequilibrium between the growth rates of domestic supply of, and demand for money. An excess supply of money creates an excess demand for goods and services, which in turn increases the demand for foreign goods and services, and results in reserves flowing out of the domestic money market. The EMP model tests whether authorities absorb the foreign exchange pressure by drawing down on reserves or by a depreciating currency. 
Girton and Roper (1977) developed a measure for the EMP of a currency in a world of managed floating exchange rates. Their model is based on the monetary approach to the balance of payments. The monetary model is based on the notion of money demand and money supply. In particular, the model of the EMP hinges on two basic conditions. One is the condition of equilibrium in the money market and the other is the imposition of the purchasing power parity condition (Kim, 1985).

The model can be constructed with the following equations:

$$
\begin{aligned}
& M^{\mathrm{s}}=\mathrm{m}(\mathrm{R}+\mathrm{D}) \\
& \mathrm{M}^{\mathrm{d}}=\mathrm{kPY} \\
& \mathrm{E}=\mathrm{P}^{*} / \mathrm{P} \\
& \mathrm{M}^{\mathrm{s}}=\mathrm{M}^{\mathrm{d}}
\end{aligned}
$$

Identity (1) shows that changes in money supply are from either foreign or domestic sources. It shows that money supply is defined as the money multiplier $\mathrm{m}$, times base money $(\mathrm{R}+\mathrm{D})$, which is the sum of central bank's holdings of foreign assets and domestic credit. $\mathrm{M}^{\mathrm{s}}$ is measured by M1. $\mathrm{M}^{\mathrm{d}}$ in (2) and represents the Cambridge cash balance model of money demand, where $\mathrm{P}$ stands for the domestic price level and $\mathrm{Y}$ for real domestic income, while $\mathrm{k}$ is the fraction of nominal income people hold in the form of cash, and is assumed to be constant. Equation (3) is the purchasing power parity condition, where E stands for the nominal exchange rate defined as units of foreign currency per rand, and $\mathrm{P}^{*}$ is the foreign inflation. Equation (4) is the monetary equilibrium condition. Substituting equation (3) into (2), and (1) and (2) into (4), expressing everything in percentage changes and rearranging terms gives an empirical equation (5).

$\mathrm{r}+\mathrm{e}=-\mathrm{d}+\mathrm{p}^{*}+\mathrm{y}-\mathrm{a}$

Where $\mathrm{r}=\%$ change in the international reserve component of the base money; $\mathrm{e}=\%$ change in the nominal exchange rate, $\mathrm{E} ; \mathrm{d}=$ change in the domestic credit as a proportion of the base money $(\mathrm{R}+\mathrm{D}) ; \mathrm{p}^{*}=\%$ change in the foreign prices; $\mathrm{y}=\%$ change in real income, and $\mathrm{a}=$ $\%$ change in the money multiplier.

The left-hand side of equation (5) denotes the exchange market pressure. This equation gives three propositions, which will be tested on the South African data. First, an increase in real income results in proportional appreciation of the domestic currency and an inflow of foreign exchange reserves. Second, increases in the rate of growth in domestic credit or the money multiplier result in a proportional depreciation of domestic currency and an outflow of foreign exchange reserves. Third, an increase in foreign inflation rates results in a proportional appreciation of the domestic currency and an inflow of foreign exchange reserves.

3

\section{Empirical literature}

Since Girton and Roper published their seminal paper in 1977, their model (or its variants) has been extensively applied to a number of countries. It has not yet been applied to the context of an African country. Girton and Roper (1977) applied their model to the experience of post-war Canada, and Connolly and Silveira (1979) to the Brazilian experience. Modeste (1981) applied the same model to the Argentine experience, while Kim (1985) applied it to Korea. Mah (1991, 1995, 1998) also applied the model to the Korean experience. The empirical results of these and other studies on EMP are summarised in Table 2 below. 
Table 2

Literature review

\begin{tabular}{|c|c|c|}
\hline Author(s) & Country(s)/period(s) & Results \\
\hline $\begin{array}{l}\text { Girton and } \\
\text { Roper (1977) }\end{array}$ & $\begin{array}{l}\text { Canada, } \\
1952-1974\end{array}$ & $\begin{array}{l}\text { The growth rate of domestic credit and the growth } \\
\text { rate of domestic income are significant and have the } \\
\text { expected sign. The coefficient for the variable } Q \text { is } \\
\text { not significant. }\end{array}$ \\
\hline $\begin{array}{l}\text { Connolly and } \\
\text { Silveira (1979) }\end{array}$ & $\begin{array}{l}\text { Brazil, } \\
1955-1975 \text { and } 1962-1975\end{array}$ & $\begin{array}{l}\text { Domestic credit, foreign inflation and domestic } \\
\text { income perform well in the latter sample; all } \\
\text { variables are significant, with the expected signs. In } \\
\text { the earlier sample period, only domestic credit is } \\
\text { significant. The Q variable is insignificant. }\end{array}$ \\
\hline Kim (1985) & $\begin{array}{l}\text { Korea, } \\
1980-1983\end{array}$ & $\begin{array}{l}\text { Domestic credit and real wage income are } \\
\text { significant, with expected signs except for the foreign } \\
\text { rate of inflation. }\end{array}$ \\
\hline Mah (1991) & $\begin{array}{l}\text { Korea, } \\
1980-1987\end{array}$ & $\begin{array}{l}\text { Domestic credit, domestic income and foreign } \\
\text { inflation all have the expected sign and are } \\
\text { significant. The variable } Q \text { is insignificant. When } r \\
\text { only is used as the dependent variable the coefficient } \\
\text { of determination is lower. }\end{array}$ \\
\hline Mah (1995) & $\begin{array}{l}\text { Korea, } \\
1980-1989\end{array}$ & $\begin{array}{l}\text { Domestic credit, domestic income and foreign } \\
\text { inflation all have the expected sign and are } \\
\text { significant. When r only is used as the dependent } \\
\text { variable the coefficient of determination is much } \\
\text { lower. }\end{array}$ \\
\hline Mah (1998) & $\begin{array}{l}\text { Korea, } \\
1980-1993\end{array}$ & $\begin{array}{l}\text { Domestic credit, trade-weighted foreign wholesale } \\
\text { price index, domestic real income and money } \\
\text { multiplier are significant, with expected signs. }\end{array}$ \\
\hline $\begin{array}{l}\text { Modeste } \\
(1981)\end{array}$ & $\begin{array}{l}\text { Argentina, } \\
1972-1978\end{array}$ & $\begin{array}{l}\text { Domestic credit, domestic income and foreign } \\
\text { inflation all have the expected sign and are } \\
\text { significant except for the foreign inflation. The Q } \\
\text { variable is insignificant. }\end{array}$ \\
\hline $\begin{array}{l}\text { Shiva and } \\
\text { Bahmani- } \\
\text { Oskooee } \\
\text { (1998) }\end{array}$ & $\begin{array}{l}\text { Iran, } \\
1959-1990\end{array}$ & $\begin{array}{l}\text { Using the black market exchange rate, domestic } \\
\text { credit, foreign inflation (US), real domestic income } \\
\text { and the money multiplier are all significant, with the } \\
\text { expected sign, except for the foreign inflation. The } \\
\text { coefficient of Q is negative and significant. Using } \\
\text { the official exchange rate, only domestic credit and } \\
\text { the money multiplier are significant and have the } \\
\text { expected sign. }\end{array}$ \\
\hline
\end{tabular}




\section{4}

\section{Empirical Results}

\section{Table 3}

The OLS estimates of the EMP model (1970-1993)

\begin{tabular}{|l|c|c|c|c|c|c|c|}
\hline $\begin{array}{l}\text { Dependent } \\
\text { variable }\end{array}$ & $\mathbf{d}$ & $\mathbf{P}^{*}$ & $\mathbf{Q}$ & $\mathbf{y}$ & $\mathbf{a}$ & $\mathbf{a d j .} \mathbf{R}^{\mathbf{2}}$ & $\mathbf{D . W}$ \\
\hline$(1) \mathrm{r}+\mathrm{e}$ & -83.79 & 0.0597 & & 0.185 & -0.722 & 0.68 & 2.355 \\
& $(-6.381)$ & $(0.048)$ & & $(0.154)$ & $(-6.29)$ & & 2.67 \\
$(2) \mathrm{r}$ & -73.97 & -0.658 & & 0.700 & -0.662 & 0.67 & \\
& $(6.212)$ & $(0.532)$ & & $(0.645)$ & $(-6.37)$ & & 1.77 \\
$(3) \mathrm{e}$ & -9.82 & 0.717 & -0.36 & -0.516 & -0.060 & 0.020 & \\
& $(-1.54)$ & $(1.08)$ & $(-0.90)$ & $(-0.885)$ & $(-1.07)$ & & 2.21 \\
$(4) \mathrm{r}+\mathrm{e}$ & -82.47 & -0.017 & & -0.092 & -0.74 & 0.67 & \\
& $(-6.21)$ & $(-0.01)$ & & $(-0.074)$ & $(-6.32)$ & & \\
\end{tabular}

Note: The empirical results are based on annual data. The numbers in the parentheses below the estimated coefficients are the t-values.

Source: Data from International Financial Statistics

Using annual South African data over the period 1970-1993, the EMP is estimated. The results are reported in Table 3 above. The regression (1) reports the estimate of the EMP model when the dependent variable is the sum of $e$ and $r$, which is a measure of EMP. The results of this regression provide evidence in support of the EMP model. All estimated coefficients carry expected signs and those for domestic credit and money multiplier differ significantly from zero, as shown by the high t-values. The estimated coefficients for domestic real income and foreign inflation are not significantly different from zero, even at 10 per cent level of significance. Despite this, an F-value of 12.56 ( $p$-value 0.00005) indicates that these four variables together are useful in explaining the combined variation in the balance of payments and the exchange rate. The explanatory power of the model is illustrated in Figure 1 below, where the actual and predicted movements in $(\mathrm{r}+\mathrm{e})$ are compared.

Figure 1

Relationship between actual and estimated EMP

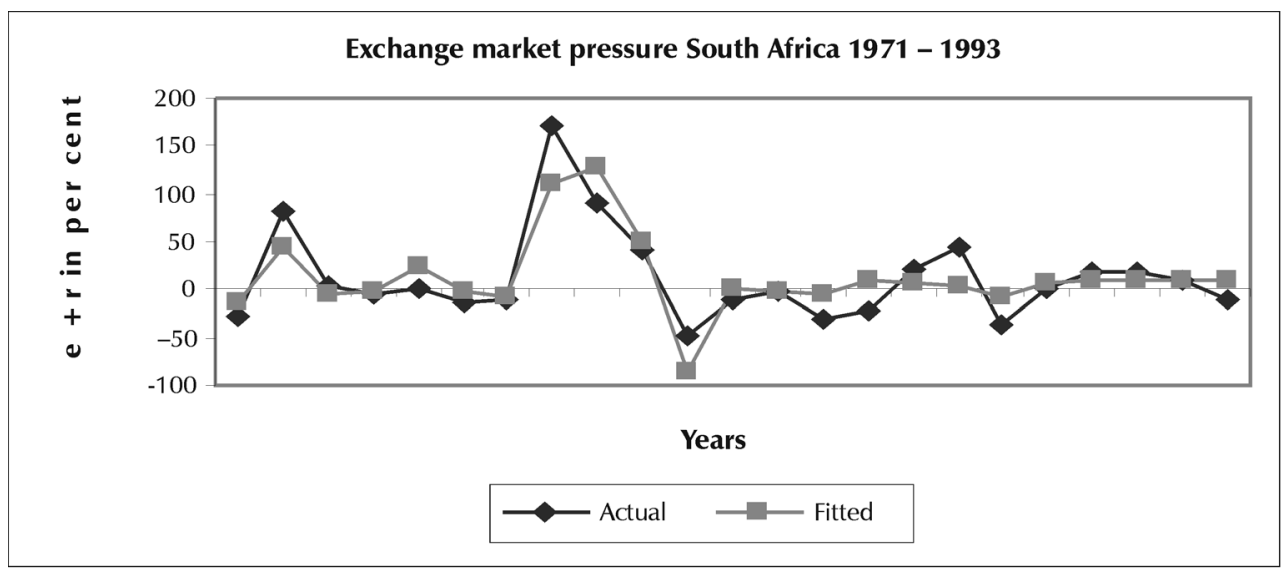


Regression (2) reports the results when only $r$ is used as the dependent variable. As can be seen in Table 3, all the estimated coefficients carry their expected signs, except for the foreign inflation, which is now negative. It can also be seen that real domestic income and foreign inflation are again not statistically different from zero at any reasonable level of significance, and that the adjusted $\mathrm{R}^{2}$ is slightly lower than when $(e+r)$ is used.

Regression (3) reports the results when only $\mathrm{e}$ is used as the dependent variable. It is evident that this model does not fit the data. First, all the estimated coefficients are statistically insignificant at any reasonable significance level. Second, the $\mathrm{R}^{2}$ is very low (0.198), with an adjusted $\mathrm{R}^{2}$ of only 0.02 .

Taking earlier literature into account, it is hypothesised that the magnitude of market pressure, defined as $(\mathrm{r}+\mathrm{e})$, is independent of whether the authorities absorb EMP in the exchange rate or foreign exchange reserves. This was tested by including the variable $\mathrm{Q}=$ $(\mathrm{e}-1) /(\mathrm{r}-1)$ as one of the explanatory variables on the right-hand side of the EMP equation (5). If the monetary authorities allow the pressure to be alleviated by depreciation relative to reserve losses, the greater is $\mathrm{Q}$. The regression results, which include the $Q$ variable, are shown in regression (4) in Table 4 above. As can be seen, compared to regression (1), there is a change in signs for income and foreign inflation variables, but there is no change in significance of the estimated coefficients. The variable Q is statistically insignificant. The insignificance of the $\mathrm{Q}$ variable implies a one-to-one tradeoff between reserve losses and exchange rate depreciation for the monetary authorities over the study period. This result is similar to that reported by Girton and Roper for Canada and by Connolly and Silveira for Brazil.

After the parameters of the model had been estimated, diagnostic tests were used to check whether the specification of the EMP model was correct. Normality of the regression residuals of EMP $(r+e)$ was checked using the Jarque-Bera test. The Jarque-Bera statistic, shown in Table 4 in the appendix, is calculated as 1.87 (p-value $=0.393$ ), which indicates no rejection of the normality null hypothesis at any reasonable level of significance. Ljung-Box Q statistic for up to $6^{\text {th }}$ order serial correlation in the residuals takes the value $\mathrm{Q}=6.286$ ( $\mathrm{p}$-value $=0.392$ ), which does not reject the null hypothesis of no serial correlation in the residuals. The White test statistic for heteroscedasticity was 12.03 $(\mathrm{p}$-value $=0.150)$ and does not reject the null hypothesis of homoscedastic residuals. The other tests are also reported in Table 4. The cusum and cusum square tests (in Figure 2) for the stability of the regression do not reject the null hypothesis of a stable regression at 5 per cent level of significance, and are shown in Figure 2 below. When $r$ is used as the dependent variable, there is evidence of non-normality, as reported in Table 5 in the appendix.

\section{Figure 2}

Recursive Residuals Tests for exchange market pressure
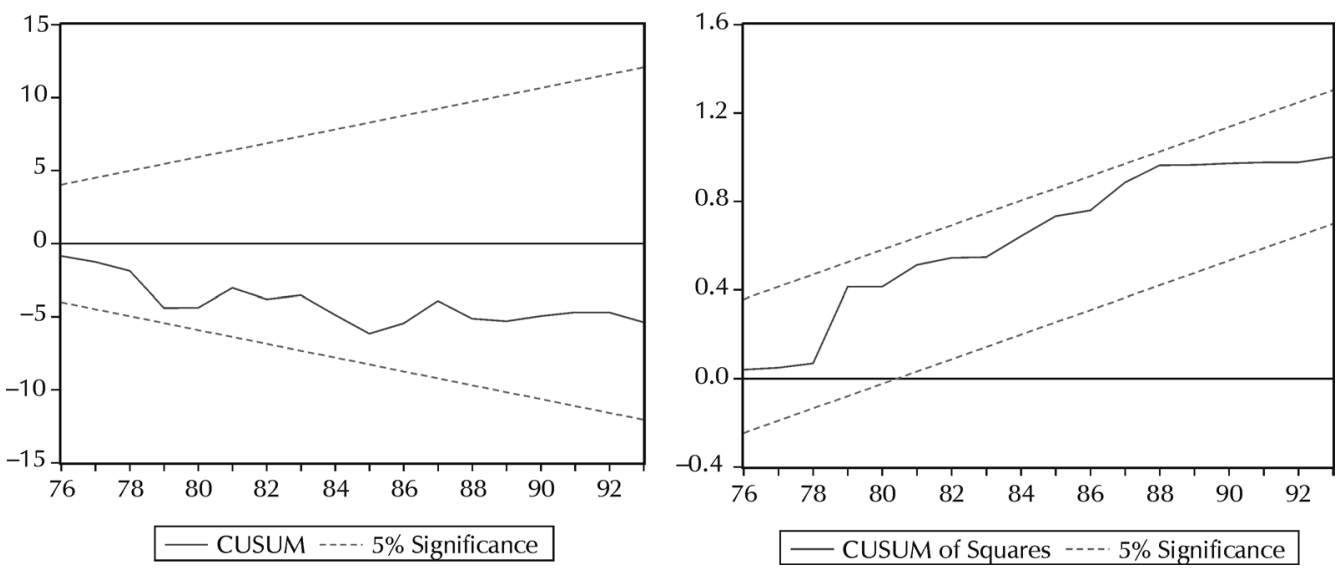


\section{5}

\section{Evidence from raw data}

An attempt is made to analyse the raw data based on the sample period 1970-2004. It is evident from Figure 3 that the relationship between EMP and foreign inflation is positive. Figure 4 shows a negative relationship between EMP and domestic credit growth rate. It is also evident from Figures 5 and 6 that the EMP is negatively related to the rate of change in the money multiplier and positively related to real domestic income.

\section{Figure 3}

Trends in EMP and foreign prices (US)

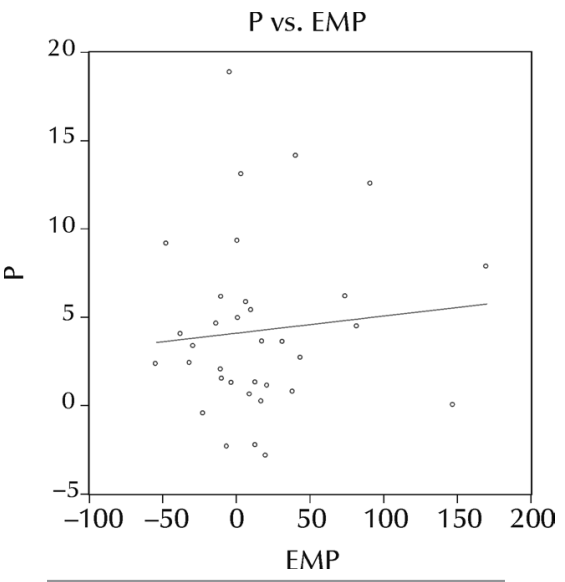

Figure 4

Trends in EMP and domestic credit

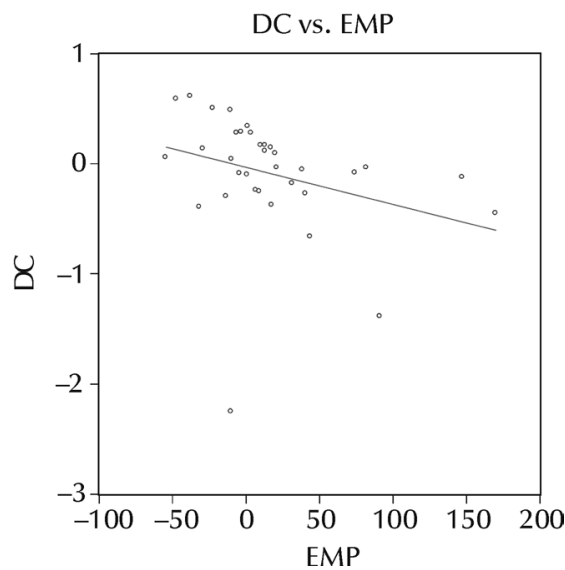

Figure 5

Trends in EMP and money multiplier

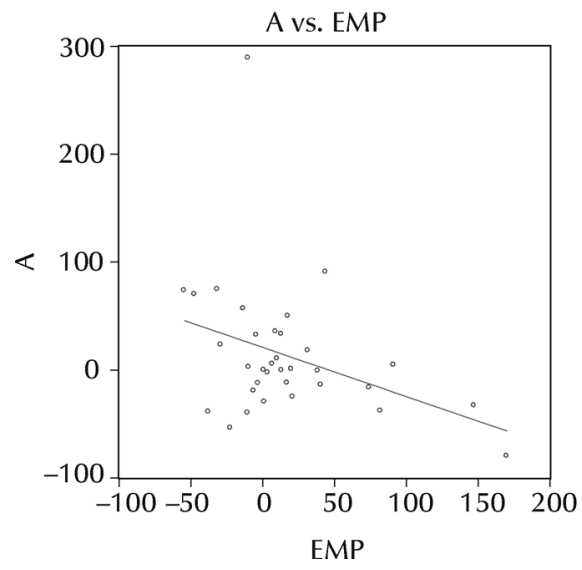

Figure 6

Trends in EMP and income

Yvs. EMP

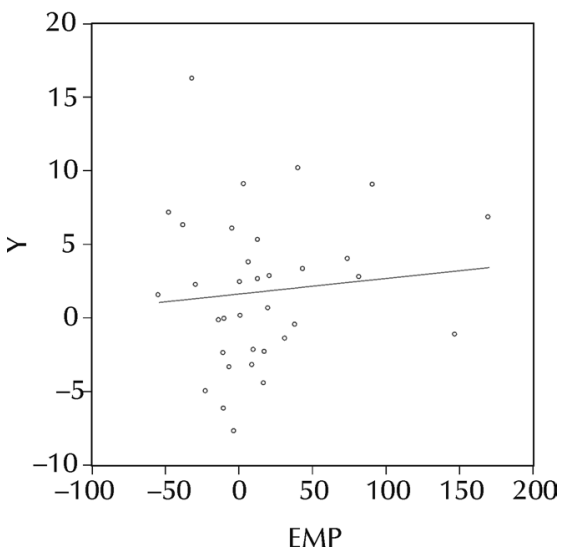

6

\section{Summary and conclusion}

In this study, a monetary model of EMP was applied to the South African experience. Using annual data for the period 1970-1993, the empirical analysis suggests that the South African experience during the study period provides another good example of a country that alleviated imbalances in its external sector by combining changes in its reserves with changes in its exchange rate. Evidence shows that the monetary model is better than models that use changes only in foreign reserves 
or the exchange rate. Empirical analysis also shows that there is strong negative relationship between the rates of domestic credit creation, money multiplier growth and the rates of change in the EMP. We do not find evidence of the impact of domestic real income on EMP. The variable $Q$ is insignificant. This implies that, over the study period, the South African monetary authorities responded to EMP by depreciating currency and losing international reserves. In a managed floating exchange rate system, the policy prescription emerging from this study is that contractionary monetary policy can be used to maintain exchange rate stability in an economy.

\section{Appendix}

\section{Table 4}

Diagnostic test: EMP $(\alpha=5 \%)$

\begin{tabular}{|l|l|c|c|l|}
\hline Purpose of the test & Test & Test statistic & P-value & Decision \\
\hline Normality & Jarque-Bera & 1.87 & 0.393 & $\begin{array}{l}\text { Normally } \\
\text { distributed }\end{array}$ \\
\hline Heteroskedasticity & White & 12.03 & 0.150 & $\begin{array}{l}\text { No } \\
\text { heteroskedasticity }\end{array}$ \\
\hline Heteroskedasticity & ARCH LM & 0.012 & 0.914 & $\begin{array}{l}\text { No } \\
\text { heteroskedasticity }\end{array}$ \\
\hline Serial correlation & Durbin-Watson & 2.355 & & No decision \\
\hline Serial correlation & Ljung-Box Q & 6.286 & 0.392 & $\begin{array}{l}\text { No serial } \\
\text { correlation }\end{array}$ \\
\hline Stability & CUSUM & & & Stable \\
\hline Stability & Cusum Square & & & Stable \\
\hline
\end{tabular}

Table 5

Diagnostic test: $r(\alpha=5 \%)$

\begin{tabular}{|l|l|l|l|l|}
\hline Purpose of the test & \multicolumn{1}{l}{ Test } & 6.974 & 0.031 & $\begin{array}{l}\text { Not normally } \\
\text { distributed }\end{array}$ \\
\hline Normality & Jarque-Bera & 11.174 & 0.192 & $\begin{array}{l}\text { No } \\
\text { heteroskedasticity }\end{array}$ \\
\hline Heteroskedasticity & White & 0.077 & 0.781 & $\begin{array}{l}\text { No } \\
\text { heteroskedasticity }\end{array}$ \\
\hline Heteroskedasticity & ARCH LM & 2.666 & & No decision \\
\hline Serial correlation & Durbin-Watson & 12.533 & 0.051 & $\begin{array}{l}\text { No serial } \\
\text { Correlation }\end{array}$ \\
\hline Serial correlation & Ljung-Box Q & & & Stable \\
\hline Stability & CUSUM & & & Unstable \\
\hline Stability & Cusum Square & & & \\
\hline
\end{tabular}


Table 6

South African exchange market pressure: 1971-1993

\begin{tabular}{|c|c|c|c|}
\hline Year & e & $\mathbf{r}$ & $e+r$ \\
\hline 1971 & -6.25 & -22.76 & -29.01 \\
\hline 1972 & -2.30 & 84.50 & 82.20 \\
\hline 1973 & 16.69 & -12.93 & 3.76 \\
\hline 1974 & -2.71 & -1.48 & -4.20 \\
\hline 1975 & -20.69 & 21.74 & 1.06 \\
\hline 1976 & 0.00 & -13.26 & -13.26 \\
\hline 1977 & 0.00 & -09.99 & -9.99 \\
\hline 1978 & 0.00 & 170.10 & 170.10 \\
\hline 1979 & 5.15 & 86.33 & 91.48 \\
\hline 1980 & 10.86 & 29.93 & 40.79 \\
\hline 1981 & -22.05 & -25.15 & -47.20 \\
\hline 1982 & -11.06 & 0.83 & -10.23 \\
\hline 1983 & -11.95 & 9.02 & -2.93 \\
\hline 1984 & -38.44 & 7.09 & -31.35 \\
\hline 1985 & -22.40 & 0.10 & -22.30 \\
\hline 1986 & 17.18 & 3.02 & 20.20 \\
\hline 1987 & 13.12 & 30.87 & 43.99 \\
\hline 1988 & -18.85 & -18.71 & -37.56 \\
\hline 1989 & -6.23 & 7.67 & 1.44 \\
\hline 1990 & -1.05 & 18.87 & 17.82 \\
\hline 1991 & -6.56 & 23.84 & 17.28 \\
\hline 1992 & -10.15 & 19.48 & 9.32 \\
\hline 1993 & -10.14 & 0.54 & -9.60 \\
\hline
\end{tabular}

Note: There are minor inconsistencies due to rounding.

All data are annual for the period 1970-1993 and were collected from The International Financial Statistics of the IMF, various issues.

\section{Data and data sources}

Variables in the EMP model (equation (5): $\mathrm{r}=\%$ change in the international reserve component of the base money $(\mathrm{R}+\mathrm{D})$ where $\mathrm{R}$ and $\mathrm{D}$ are defined below.
$\mathrm{R}=$ South African Reserve Bank's foreign assets (in millions of rand), line 11.

$\mathrm{D}=$ domestic credit, in millions of rand, line 32.

$\mathrm{e}=$ percentage change in the bilateral exchange rate of the domestic currency vis-à-vis the United States dollar, E, measured as the volume of the foreign currency that can be purchased 
with one unit of domestic currency. Using this definition e $>0$ reflects an appreciation, while $\mathrm{e}<0$ reflects a depreciation of the domestic currency.

$\mathrm{p}^{*}=$ rate of change in world prices measured by the rate of change of the US wholesale price index (converted to base year 1975), line 63.

$y=\%$ change in real domestic income of South Africa measured by the percentage change in the manufacturing production index $(1970=$ 100), line 66 eyc.

$\mathrm{a}=$ rate of change of money multiplier. The money multiplier, $\mathrm{m}$, is obtained by dividing money supply, $\mathrm{M}$, by the monetary base $(\mathrm{R}+\mathrm{D})$. The definition of money supply used is M1, in millions of rand, line 34 .

$\mathrm{d}=\Delta \mathrm{D} /(\mathrm{R}+\mathrm{D})$ where $\mathrm{R}$ and $\mathrm{D}$ are as defined above.

$\mathrm{Q}=(\mathrm{e}-1) /(\mathrm{r}-1)$, where $\mathrm{e}$ and $\mathrm{r}$ are as defined above. This measures whether the EMP is independent of its composition, e and r. If it is statistically significant, then EMP is influenced by its components, that is, e and $r$.

\section{References}

1 BAHMANI-OSKOOEE, M. \& SHIVA, R. (1998) "A method of detecting whether a central bank engages in the black market for foreign exchange: Evidence from Iran”, Economics Letters, 60: 97103.
2 CONNOLLY, M. \& SILVEIRA, J.D.D. (1979)

"Exchange market pressure in postwar Brazil: An application of the Girton-Roper monetary model", American Economic Review, 69(3): 448-454.

3 GIDLOW, R. (2004) "Modifications in South African exchange rate policies 1998-2001”, South African Journal of Economic History, 19 (1): 18- 41.

4 GIRTON, L. \& ROPER, D. (1977) "A monetary model of exchange market pressure applied to the postwar Canadian experience", American Economic Review, 67(3): 537-548.

5 INTERNATIONAL MONETARY FUND, International Financial Statistics, IMF:

Washington, various issues.

6 INTERNATIONAL MONETARY FUND (2004) Public Information Notice (PIN) No. 01/44 http:// www.imf/external/np/sec/pn/2004/pn0467.htm

7 KIM, I. (1985) "Exchange market pressure in Korea: An application of the Girton-Roper monetary model: Note", Journal of Money, Credit and Banking, 17(2): 258-263.

8 MAH, S.J. (1991) "A note on the exchange market pressure: The Korean experience, 1980-1987", Applied Economics, 23: 587-590.

9 MAH, S.J. (1995) "An analysis of the structural change in the exchange market pressure: Korea, 1980-89", Applied Economics Letters, 2: 80-82.

10 MAH, S.J. (1998) "Exchange market pressure in Korea: Dynamic specifications", Applied Economics Letters, 5: 765-768.

11 MODESTE, N.C. (1981) "Exchange market pressure during the 1970s in Argentina: An application of the Girton-Roper monetary model", Journal of Money, Credit and Banking, 13: 234-40.

12 VAN DER MERWE, E.J. 1996 "Exchange rate management policies in South Africa: Recent experience and prospects", South African Reserve Bank, Occasional Paper No. 9. 